\title{
ВПЛИВ НЕЙРОТРОПНИХ ПРЕПАРАТІВ МЕТАБОЛІЧНОЇ ДІЇ НА ЕМБРІОНАЛЬНИЙ ПРИРІСТ ПОРОСЯТ ТА ВИХІД ПОРОСЯТ ПРИ НАРОДЖЕННІ
}

\author{
Безверха Любов Миколаївна \\ кандидат сільськогосподарських наук \\ Житомирський агротехнічний коледж \\ ORCID: 0000-0003-2518-972X \\ E-mail: lubov_bezverxa@ukr.net
}

Трохименко Віта Зигмундівна кандидат сільськогосподарських наук, доцент Поліський національний університет ORCID: 0000-0002-1763-3141

E-mail: trohimenkovita@ukr.net

Ходаківська Надія Іванівна викладач-методист

Житомирський агротехнічний коледж ORCID: 0000-0002-6045-9564

E-mail: Lesyanadya@ukr.net

Захарін В'ячеслав Васильович кандидат ветеринарних наук, доцент Поліський національний університет ORCID: 0000-0002-4157-644X

E-mail: zakharin35@ukr.net

Інтенсифікація галузі свинарства має передбачати максимальне використання біологічних особливостей свиней не тільки через забезпечення прогресивних методів розведення і годівлі, але і шляхом застосування нових біотехнологічних методів стимуляиії відтворювальної здатності тварин. У статті незаведені результати досліджень по вивченню впливу біологічно активних препаратів «Глютам 1М» та «Стимулін Вет» на збільшення кількості ділових поросят, за рахунок стимулювання швидкості росту живих поросят в ембріональний період. Досліди проводились на агрокомбінаті "СВАТ Калита» смт. Калита, Броварського району, Київської області на свиноматках породи велика біла. У кожному з цих дослідів було сформовано 3 групи свиноматок великої білої породи по 30 голів, після першого та другого опоросу. Свиноматкам І-ої та II-ої дослідних груп застосовували біологічно активні препарати на 1-3 дні статевого циклу в дозі 20 мл; І-й групі - 18\% «Глютам 1М» (загальна доза 10,8 2), II-й - «Стимулін-Вет». Тваринам контрольних груп згодовували по 20 мл фізіологічного розчину. Препарат згодовували вранці під час годівлі тварин. Годівлю свиноматок здійснювали два рази на добу: вранці та ввечері. Тварини забезпечується повноцінним комбікормом власного виробництва за спеціальною рецептурою СК-6. За результати досліджень було встановлено, що згодовування свиноматкам у фізіологічно напружений період статевого циклу метаболічно-нейротропних препаратів «Глютам 1М» та «Стимулін Вет» 1-3-й дні сфртатевого циклу позитивно позначалося на швидкості росту тварин, головним чином за рахунок підвищення кількості новонароджених поросят та сприяло збільшенню кількості ділових поросят, а також вірогідно більшій їх масі, при класі 1,51 і більше ке.

Ключові слова: статевий цикл, поросята, ембріональний період, відтворювальна здатність.

DOI: https://doi.org/10.32845/bsnau.lvst.2021.1.6

Раціональне ведення даної галузі базується на зниженні показників неплідності маточного поголів'я, підвищенні заплідненості самок, отриманні максимальної кількості приплоду від кожної свиноматки та зменшенні ембріональної смертності $[3,7]$.

Одним із актуальних напрямів підвищення продуктивності тварин, $€$ пошук, випробування та додавання до раціону різних кормових добавок та біологічно активних речовин. Ïх використання в годівлі свиней дає можливість підвищити коефіцієнт трансформації поживних та біологічно активних речовин кормів у тваринницьку продукцію, реалізувати генетичний потенціал, підтримувати в межах фізіологічної норми відтворюванні фуункції, та життєздатність [5].

Серед багатьох вчених, особливо практиків існує ду-

мка, що поросята низької живої маси гинуть тому, що вони народжуються фізіологічно незрілими. Однак, дослідженнями науковців доведено, що всі системи організму у поросят нижче 0,8-0,9 кг функціонують нормально, за виключенням недостатньо розвиненої м'язової тканини. При правильному утриманні такого молодняку вдається досягти хорошого розвитку та приростів навіть у таких поросят [6].

В умовах традиційного свинарства - це можливо навіть вигідно. Але, на промислових комплексах при ритмічному виробництві свинини новонароджені поросята, які суттєво відрізняються по живій масі вимагають додаткових затрат праці при формуванні однорідних гнізд і догляді за поросятами низької маси, а це є економічно не вигідно [10].

Тому інтенсифікація галузі свинарства має передба- 
чати максимальне використання біологічних особливостей свиней не тільки через забезпечення прогресивних методів розведення і годівлі, але і шляхом застосування нових біотехнологічних методів стимуляції відтворювальної здатності тварин, що дозволить раціонально використовувати засоби виробництва, знизити собівартість продукції і покращити умови праці та зробити галузь свинарства економічно ефективною та конкурентоспроможною $[10,12]$. Для стимуляції відтворювальної здатності самок використовують вітамінні [11], нейротропні [4], гепатотропні [8], імуномоделюючі [9] та гормональні препарати $[1,2,7]$. Але ці засоби, як правило, використовують на невеликому поголів"ї тварин, вони $є$ досить дороговартісними, їх ін'єктують, що створює додаткові затрати праці та часу, а також тривале їх застосування може справляти негативний вплив на статеву систему та організм самки в цілому [1].

Було встановлено, що згодовування свиноматкам у фізіологічно напружений період статевого циклу метаболічно-нейротропних препаратів «Глютам $1 \mathrm{M}$ » та «Стимулін Вет» 1-3-й дні статевого циклу зумовлює покращення їхньої відтворювальної здатності, за рахунок інтенсифікації функціональної активності жовтих тіл і фолікулів на яєчниках свиноматок, про що свідчить підвищення вмісту в крові прогестерону на 4-й та 7-й дні статевого циклу на 40,2 \% та $18 \%$ та 17ß-естрадіолу в обох випадках на 8,3\%, що сприяло вірогідному збільшенню заплідненості, багатоплідності та великоплідності, відповідно на 11,4 \%, 12,6 \% та $5,4 \%[13,14,15,16,17,18]$.

Мета досліджень полягала у вивченні впливу біологічно активних препаратів «Глютам $1 \mathrm{M»} \mathrm{та} \mathrm{«Стимулін} \mathrm{Вет»}$ на збільшення кількості ділових поросят, за рахунок стимулювання швидкості росту живих поросят в ембріональний період.

Матеріали та методи досліджень. Досліди прово- дились на агрокомбінаті «СВАТ Калита» смт. Калита, Броварського району, Київської області на свиноматках породи велика біла. У кожному з цих дослідів було сформовано 3 групи свиноматок великої білої породи по 30 голів, після першого та другого опоросу. Свиноматкам I-ої та II-ої дослідних груп застосовували біологічно активні препарати на 1-3 дні статевого циклу в дозі 20 мл; І-й групі - 18\% «Глютам $1 \mathrm{M»} \mathrm{(загальна} \mathrm{доза} \mathrm{10,8} \mathrm{г),} \mathrm{II-й} \mathrm{-} \mathrm{«Стимулін-Вет».} \mathrm{Тваринам}$ контрольних груп згодовували по 20 мл фізіологічного розчину. Препарат згодовували вранці під час годівлі тварин. Годівлю свиноматок здійснювали два рази на добу: вранці 9.00-9.30 та ввечері 15.00-15.30. Тварини забезпечується повноцінним комбікормом власного виробництва за спеціальною рецептурою СК-6. За два тижні до опоросу свиноматок переводили в хліви-маточники. У хлівах-маточниках їх утримували в одиночних станках у фіксованому стані, 3 метою попередження травмування та загибелі новонароджених поросят, де вони знаходились 28-30 днів - до відлучення. Свиноматок у статевій охоті відбирали два рази на добу за допомогою кнура-пробника. Вибраних свиноматок розташовували в індивідуальних станках і осіменяли штучно попередньо розбавленою спермою два рази з проміжком у 18 годин. Перед штучним осіменінням свиноматок утримували в групових станках по 15 гол.

Результати досліджень засвідчили, що у І-й дослідній групі кількість ділових поросят в зимовий період була більшою на 4,2 \% порівняно 3 тваринами контрольної групи. Тоді, як у ІІ-й дослідній групі їх кількість була майже однаковою з контролем (табл. 1). В той час як маса ділових поросят у І-й і II-й дослідних групах вірогідно на 7,8 \% та 5,4 \% переважала контроль.

Кількість не ділових поросят у І-й дослідній групі була меншою на $4,2 \%$, а їх маса - більшою на $5,5 \%$.

Кількісний та відносний вихід ділових поросят у піддослідних свиноматок

Таблиця 1

\begin{tabular}{|c|c|c|c|c|c|c|}
\hline \multirow{4}{*}{ Поросята } & \multicolumn{6}{|c|}{ Група } \\
\hline & \multirow{2}{*}{\multicolumn{2}{|c|}{ контрольна }} & \multicolumn{4}{|c|}{ дослідна } \\
\hline & & & & & & \\
\hline & $\mathrm{n} / \%$ & $\mathrm{M} \pm \mathrm{m}$ & $\mathrm{n} / \%$ & $\mathrm{M} \pm \mathrm{m}$ & $\mathrm{n} / \%$ & $\mathrm{M} \pm \mathrm{m}$ \\
\hline \multirow{2}{*}{ Ділові, кг } & $198 /$ & $1,41 \pm$ & 2671 & $1,53 \pm$ & $254 /$ & $1,49 \pm$ \\
\hline & 94,7 & 0,015 & 98,9 & $0,011^{3}$ & 94,4 & $0,013^{3}$ \\
\hline Не ділові, кг & $\begin{array}{l}11 / \\
53\end{array}$ & $0,69 \pm$ & $\begin{array}{l}3 / \\
11\end{array}$ & $0,73 \pm$ & $\begin{array}{c}8 / \\
31\end{array}$ & $0,64 \pm$ \\
\hline
\end{tabular}

Примітка: ${ }^{3} p \leq 0,001$ - порівняно з контролем

У ॥-й групі кількість поросят даної категорії була майже однаковою з контролем, а їх жива маса на 7,3 \% меншою.

Тобто, згодовування препарату «Глютам 1М» сприяло збільшенню кількості ділових поросят, а також вірогідно більшій їх масі.

На думку деяких учених, ембріональна смертність $€$ фактором природного відбору на ранніх періодах розвитку зародків. Незважаючи на те, що це явище закономірне і сприяє збереженню продуктивності стад і порід свиней, основним завданням є підвищення виходу зрілих яйцеклітин під час овуляції до 20 в одному статевому циклі, щоб таким чином за їх рахунок збільшилася багатоплідність до 12-14 поросят на опорос [9].

Швидкість росту піддослідних живих поросят всіх груп в ембріональний період був майже однаковим. Водночас прирости мертвонароджених тварин були меншими на $7,1 \%$ та 20,9 \% порівняно 3 контрольними і вірогідно на 14,8 \% та 26,5 \% порівняно з живими поросятами (табл. 2). 
Таблиця 2

Середньодобові прирости поросят в ембріональний період за згодовування біологічно-активних препаратів

\begin{tabular}{|c|c|c|c|c|c|c|}
\hline \multirow{4}{*}{ Показник } & \multicolumn{6}{|c|}{ Група } \\
\hline & \multicolumn{2}{|c|}{ контрольна } & \multicolumn{4}{|c|}{ дослідна } \\
\hline & \multirow{2}{*}{$\mathrm{n}$} & \multirow{2}{*}{$M \pm m$} & \multicolumn{2}{|c|}{ I } & \multicolumn{2}{|c|}{$\|$} \\
\hline & & & $\mathrm{n}$ & $\mathrm{M} \pm \mathrm{m}$ & $\mathrm{n}$ & $\mathrm{M} \pm \mathrm{m}$ \\
\hline Загальний приріст, г & 224 & $\begin{array}{c}12,96 \pm \\
0,733\end{array}$ & 282 & $\begin{array}{c}13,16 \pm \\
0,107\end{array}$ & 269 & $\begin{array}{c}12,96 \pm \\
0,405\end{array}$ \\
\hline Приріст живих поросят, г & 209 & $\begin{array}{c}13,04 \pm \\
0,782\end{array}$ & 270 & $\begin{array}{c}13,24 \pm \\
0,106\end{array}$ & 262 & $\begin{array}{c}13,06 \pm \\
0,413\end{array}$ \\
\hline Приріст мертвих поросят, г & 15 & $\begin{array}{c}12,14 \pm \\
0,578\end{array}$ & 12 & $\begin{array}{l}11,28 \pm \\
0,541^{3}\end{array}$ & 7 & $\begin{array}{l}9,60 \pm \\
1,585^{1}\end{array}$ \\
\hline
\end{tabular}

Примітка: ${ }^{1} p \leq 0,05 ;{ }^{3} p \leq 0,001$ порівняно з живими поросятами.

Установлено, що між масою поросят при народженні, їх збереженістю і подальшим розвитком існує пряма залежність [10]. Тому, ми провели розподіл поросят за класами по живій масі.

У І-й (глютам 1 М) піддослідній групі поросята із живою масою 0,5-0,69 кг були відсутні. У ІІ-й (стимулін-вет) групі їх кількість переважала контроль на 57,6 \% (табл. 3).

Кількість поросят у класі 0,7-0,89 кг в І-й дослідній групі нараховувала 3 голови - 1,1% від їх загальної кількос- ті в групі, що менше, ніж у контролі на 63,6 \%. В той час як в II-й дослідній та контрольній групі кількість таких тварин була однаковою.

У І-й та II-й дослідних групах число поросят з масою тварин в межах 0,9-1,1 кг становило 5 (1,9\%), та 8 (3,1\%), що менше ніж у контролі на 80,0 \% та 67,0 \%, відповідно.

Кількість тварин 3 живою масою 1,11-1,3 кг в контролі переважала тварин І-ї дослідної групи на 30,8 \%. У ІІ-й дослідній групі їх кількість була однаковою з контролем.

Таблиця 3

Класи за живою масою новонароджених поросят у свиноматок, яким згодовували біологічно-активні препарати

\begin{tabular}{|c|c|c|c|c|c|c|}
\hline \multirow{4}{*}{ Клас } & \multicolumn{6}{|c|}{ Група } \\
\hline & \multirow{2}{*}{\multicolumn{2}{|c|}{ контрольна }} & \multicolumn{4}{|c|}{ дослідна } \\
\hline & & & \multicolumn{2}{|c|}{ I } & \multicolumn{2}{|c|}{ II } \\
\hline & $\mathrm{n} / \%$ & $M \pm m$ & $\mathrm{n} / \%$ & $M \pm m$ & $\mathrm{n} / \%$ & $M \pm m$ \\
\hline $0,50,69$ & $3 / 1,4$ & $0,14 \pm 0,078$ & $-1-$ & - & $9 / 3,4$ & $0,33 \pm 0,098$ \\
\hline $0,7-0,89$ & $7 / 3,3$ & $0,33 \pm 0,105$ & $3 / 1,1$ & $0,12 \pm 0,066$ & $6 / 2,3$ & $0,25 \pm 0,090$ \\
\hline $0,9-1,1$ & $21 / 10,0$ & $1,00 \pm 0,169$ & $5 / 1,9$ & $0,20 \pm 0,082$ & $8 / 3,1$ & $0,33 \pm 0,098$ \\
\hline $1,11-1,3$ & $28 / 13,4$ & $1,33 \pm 0,126$ & $23 / 8,5$ & $0,92 \pm 0,152$ & $32 / 12,2$ & $1,33 \pm 0,155$ \\
\hline $1,31-1,5$ & $96 / 45,9$ & $4,57 \pm 0,224$ & $98 / 36,3$ & $3,92 \pm 0,215$ & $108 / 41,2$ & $4,50 \pm 0,170$ \\
\hline $1,51-1,7$ & $43 / 20,7$ & $2,05 \pm 0,176$ & $108 / 40,0$ & $4,32 \pm 0,160^{3}$ & $70 / 26,7$ & $2,92 \pm 0,248^{2}$ \\
\hline $1,71 \mathrm{i}<$ & $11 / 5,3$ & $0,52 \pm 0,160$ & $33 / 12,3$ & $1,32 \pm 0,125^{3}$ & $29 / 11,1$ & $1,21 \pm 0,180^{2}$ \\
\hline Всього: & $209 / 100$ & - & $270 / 100$ & - & $262 / 100$ & - \\
\hline
\end{tabular}

Примітка: ${ }^{2} P \leq 0,01 ;{ }^{3} P \leq 0,001$ - порівняно з контролем;

У І-й дослідній групі поросят з живою масою 1,31-1,5 кг було менше на 14,2 \% та 12,9 \% ніж в контрольній та II-й групі.

Кількість новонароджених поросят з живою масою 1,51-1,7 кг у І-й ill-й дослідних групах становила 108 (40,0 $\%), 70(26,7 \%$ ), що вірогідно більше порівняно з конролем на $52,5 \%$ та 29,8\%, відповідно.

Також збільшилась кількість поросят з живою масою 1,71 і більше, у всіх піддослідних групах порівняно з контролем. Кількість тварин даної категорії у І-й та II-й дослідних групах становила 33 (12,3 \%), 29 (11,1 \%) і вірогідно перева- жала контроль на 60,6 \% та 57,0\%.

Отже, згодовування препаратів «Глютам 1M» та «Стимулін Вет» позитивно позначалося на швидкості росту тварин, головним чином за рахунок підвищення кількості новонароджених поросят при класі 1,51 і більше кг.

Висновки. Згодовування свиноматкам на 0-3 день статевого циклу біологічно активних препаратів метаболічно-нейротропної дії «Глютам $1 \mathrm{M»} \mathrm{та} \mathrm{«Стимулін-Вет»} \mathrm{сприя-}$ ло збільшенню кількості ділових поросят, а також вірогідно більшій їх масі, при класі 1,51 і більше кг.

\section{Список використаної літератури:}

1. Башкеев Е. Д. Влияние СЖК разного биологического качества в сочетании с хориогонином на синхронизацию овуляции у свиней. Гормоны в животноводстве: бюл. науч. трудов. Дубровицы, 1981. С. 43-44.

2. Безверха Л. М., Шеремета В. І. Багатоплідність свиноматок великої білої породи за використання метаболічного препарату нейротропної дії. Науковий вісник «Асканія Нова». 2011. Вип. 4. С. 168-172.

3. Беляев В., Шахов А, Мельникова Т. Влияние селекора на воспроизводительную способность свиноматок и продуктивность их приплода. Свиноводство. 2005. №1. С. 14-15.

4. Волков М.С., Генкин А.М., Маевский Е.И. Глутаминовая кислота. Биохимические основы практического использования. Свердловск: Средне-Уральское книж. изд., 1975. 119 с.

5. Коваленко А. Л. Янтарная кислота: фармакологическая активность и лекарственные формы. Фармация. 2000. № 5-6. C. 41-43.

6. Майкл Р. Экзогенные ферменты в кормлении моногастричных животных: настоящее и будущее. Великобритания 
Animal Feed Science and Technology, 2000, v. 86, p. 1-13.

7. Инглиш П., Смит У., Мак А. Свиноматка - повышение ее продуктивности. Под ред. Г. В. Голубева. М.: Колос, 1981. $326 \mathrm{c}$.

8. Калачнюк Р., Гаврилюк І. Інтенсивність використання свиноматок. Тваринництво України. 2000. №9-10. С. 16.

9. Кокорев В. А., Кузнецов С. Г., Притков Ю. Н. Проблемы минерального питания и воспроизводства сельскохозяйственных животных. Просилактика и лечение болезней органов размножения и повышение воспроизводительной функции сельскохозяйственных животных: материалы 1 Респуб. Науч.-практ. конф. Саранск, 2002. С. 72-89.

10. Походня Г. С., Шипилов Э. А., Заложин К. К. Интенсификация воспроизводительных функций свиноматок. Белгород: Белгород ГСХА, 1998. 208 с.

11. Сарычев Н., Зеленин И., Мосин Ю. Стимуляция репродуктивной функции ремонтных свинок гормональновитаминными препаратами. Свиноводство. 1998. № 2. С. 21-23.

12. Ткачев Е. 3. Физиология питания свиней. М.: Колос, 1991. 239 с.

13. Шеремета В. И., Безверхая Л. М. Воспроизводительная способность свиноматок при введении разных препаратов. Актуальные проблемы агропромышленного производства: материалы международной научно-практической конференции. Курск, 2013. С. 295-298.

14. Шеремета В. И., Безверхая Л. М. Воспроизводительная способность свиноматок при использовании нейротропного препарата метаболического действия. Журнал научных публикаций аспирантов и докторантов. 2013. № 8 (86). С. 143145.

15. Шеремета В.І., Безверха Л.М. Вміст статевих гормонів у крові та відтворювальна здатність свиноматок за використання препарату нейротропно-метаболічної дії «Глютам 1М». Біологія тварин. 2013. Т. 15. № 2. С. 149-156.

16. Шеремета В. І., Безверха Л. М. Заплідненість свиноматок великої білої породи за використання біологічно активних препаратів. Збірник наук. праць Вінниц. нац. аграр. ун-ту. 2011. Вип. 8 (48). С. 84-88.

17. Безверха Л. М., Трохименко В. 3., Захарін В .В. Відтворювальна здатність свиноматок великої білої породи за використання біологічно активних препаратів «Глютам 1 М» та «Стимулін-вет». Вінниця.: ВЦ ВНАУ, Аграрна наука та харчові технології. 2019. Вип. 1(104) с. 94-102.

18. Шеремета В. І., Безверха Л. Н., Себа М. В., Трохименко В. З. Підвищення відтворювальної здатності свиноматки при дії препарату Глютам 1М. Фізіологічний журнал, Інститут фізіології ім. О. О. Богомольця Національної Академії Наук України. Т. 63, № 4. 2017. с. 72-79.

\section{References:}

1. Bashkeev, E. D., 1981. Vlyianye SZhK raznoho byolohycheskoho kachestva v sochetanyy s khoryohonynom na synkhronyzatsyiu ovuliatsyy u svynei [Influence of FFA of different biological quality in combination with choriogonin on the synchronization of ovulation in pigs]. Hormonы v zhyvotnovodstve: biul. nauch. trudov. Dubrovytsы - Hormones in animal husbandry: bul. scientific. works. Dubrovitsy, 43-44.

2. Bezverkha, L. M. and Sheremeta V. I., 2011. Bahatoplidnist svynomatok velykoi biloi porody za vykorystannia metabolichnoho preparatu neirotropnoi dii [Bagatoplidnist sows of the great biloiy breed for vikorystanni a metabolic preparation of neurotropic action]. Naukovyi visnyk "Askaniia Nova" - Science newsletter "Askania Nova", issue 14, pp. 168-172.

3. Beliaev, V., Shakhov, A and Melnykova T., 2005. Vlyianye selekora na vosproyzvodytelnuiu sposobnost svynomatok y produktyvnost ykh pryploda [The influence of the breeder on the reproductive ability of sows and the productivity of their litter]. Svynovodstvo - Pig breeding, issue 1, pp. 14-15.

4. Volkov, M. S., Henkyn, A. M. and Maevskyi, E. Y., 1975. Hlutamynovaia kyslota. Byokhymycheskye osnovb praktycheskoho yspolzovanyia [Glutamic acid Biochemical basis for practical use]. Sverdlovsk: Sredne-Uralsk book. ed. [in Russian].

5. Kovalenko, A. L. (2000). Yantarnaia kyslota: farmakolohycheskaia aktyvnost y lekarstvennыe formb [Succinic acid: pharmacological activity and dosage forms]. Farmatsyia - Pharmacy, issue 5-6, 41-43 [in Russian].

6. Maikl, R., 2000. Эkzohennыe fermentы v kormlenyy monohastrychnыkh zhyvotnыkh: nastoiashchee y budushchee [Exogenous Enzymes in Monogastric Animal Feeding: Present and Future]. Velykobrytanyia Animal Feed Science and Technology - UK Animal Feed Science and Technology, issue 86, 1-13.

7. Ynhlysh, P., Smyt, U. and Mak, A., 1981. Svynomatka - povbshenye ee produktyvnosty [Sow - increasing her productivity]. Moscow: Kolos.

8. Kalachniuk, R. and Havryliuk I., 2000. Intensyvnist vykorystannia svynomatok [Intensity of use of sows]. Tvarynnytstvo Ukrainy - Livestock of Ukraine, issue 9-10. 16.

9. Kokorev, V. A., Kuznetsov, S. H. and Prytkov, Yu. N., 2002. Problemb myneralnoho pytanyia y vosproyzvodstva selskokhoziaistvennыkh zhyvotnыkh [Problems of mineral nutrition and reproduction of farm animals]. Proceedings from Prevention and treatment of diseases of the reproductive organs and increasing the reproductive function of farm animals: I Respublykanskaia Nauchno-praktycheskaia konferentsyia. Saransk, pp. 72-89.

10. Pokhodnia, H. S., Shypylov, E. A. and Zalozhyn, K. K., 1998. Yntensyfykatsyia vosproyzvodytelnbkh funktsyi svynomatok [Intensification of reproductive functions of sows]. Belhorod: Belhorod HSKhA.

11. Sarbchev, N., Zelenyn, Y. and Mosyn, Yu., 1998. Stymuliatsyia reproduktyvnoi funktsyy remontnыkh svynok hormonalno-vytamynnыmy preparatamy [Stimulation of the reproductive function of gilts with hormonal and vitamin preparations]. Svynovodstvo - Pig breeding, issue 2, pp. 21-23.

12. Tkachev, E. Z., 1991. Fyzyolohyia pytanyia svynei [Physiology of pig nutrition]. Moscow: Kolos. 
13. Sheremeta, V. Y. and Bezverkhaia, L. M., 2013. Vosproyzvodytelnaia sposobnost svynomatok pry vvedenyy raznыkh preparatov [Reproductive ability of sows with the introduction of different drugs]. Proceedings from Actual problems of agroindustrial production: materials of the international scientific and practical conference: Kursk.

14. Sheremeta, V. Y. and Bezverkhaia, L. M., 2013. Vosproyzvodytelnaia sposobnost svynomatok pry yspolzovanyy neirotropnoho preparata metabolycheskoho deistvyi [Reproductive ability of sows using a neurotropic drug of metabolic action]. Zhurnal nauchnыkh publykatsyi aspyrantov y doktorantov - The journal of scientific publications of graduate and doctoral students, issue 8 (86), pp. 143-145.

15. Sheremeta, V. I. and Bezverkha, L. M., 2013. Vmist statevykh hormoniv u krovi ta vidtvoriuvalna zdatnist svynomatok za vykorystannia preparatu neirotropno-metabolichnoi dii "Hliutam 1M" [The content of sex hormones in the blood and the reproductive capacity of sows with the use of the drug of neurotropic-metabolic action "Glutam 1M"]. Biolohiia tvaryn - Animal biology, vol. 15, issue 2, pp. 149-156.

16. Sheremeta, V. I. and Bezverkha, L. M., 2011. Zaplidnenist svynomatok velykoi biloi porody za vykorystannia biolohichno aktyvnykh preparative [Fertilization of sows of large white breed with the use of biologically active drugs]. Zbirnyk naukovykh prats Vinnytsytskoho natsionalnoho ahrarnoho universytetu - Collection of scientific works of Vinnytsia National Agrarian University, issue 8 (48), pp. 84-88.

17. Bezverkha, L. M., Trokhymenko, V. Z. and Zakharin, V. V., 2019. Vidtvoriuvalna zdatnist svynomatok velykoi biloi porody za vykorystannia biolohichno aktyvnykh preparativ «Hliutam $1 \mathrm{M}$ » ta «Stymulin-vet» [Reproductive ability of sows of large white breed with the use of biologically active drugs "Glutam $1 \mathrm{M}$ " and "Stimulin-vet"]. Ahrarna nauka ta kharchovi tekhnolohii: Vinnytsia Agricultural science and food technologies: Vinnytsia, issue 1(104), pp. 94-102.

18. Sheremeta, V. I., Bezverkha, L. N., Seba, M. V. and Trokhymenko, V. Z., 2017. Pidvyshchennia vidtvoriuvalnoi zdatnosti svynomatky pry dii preparatu Hliutam $1 \mathrm{M}$ [Increasing the reproductive capacity of sows under the action of the drug Glutam $1 \mathrm{M}$ ]. Fiziolohichnyi zhurnal, Instytut fiziolohii im. O.O. Bohomoltsia Natsionalnoi Akademii Nauk Ukrainy - Journal of Physiology, Institute of Physiology. O.O. Bogomolets of the National Academy of Sciences of Ukraine, Vol. 63. issue 4, pp. 72-79.

Bezverkha Lyubov Mykolayivna, PhD in Agriculture; Zhytomyr Agrotechnical College

Trokhimenko Vita Zygmundivna, PhD in Agriculture, Associate Professor, Polissya National University

Khodakivska Nadiya Ivanivna, PhD in Agriculture, Zhytomyr Agrotechnical College

Zakharin Vyacheslav Vasyliovych, candidate of vet. Sciences, Associate Professor, Polissya National University

(Zhytomyr, Ukraine)

Influence of neurotropic drugs of metabolic action on embryonic growth of pigs and exit of pigs at birth

Intensification of the pig industry should provide for the maximum use of biological characteristics of pigs not only through the provision of advanced methods of breeding and feeding, but also through the use of new biotechnological methods to stimulate the reproductive capacity of animals. The experiments were conducted at the agricultural complex "SWAT Kalita" village. Kalita, Brovary district, Kyiv region on sows of the breed large white. In each of these experiments, 3 groups of large white sows of 30 heads were formed after the first and second farrowing. Sows of the 1st and 2nd experimental groups were treated with biologically active drugs for 1-3 days of the sexual cycle at a dose of $20 \mathrm{ml}$; Group I - 18\% "Glutam 1M" (total dose $10.8 \mathrm{~g}$ ), II - "Stimulin-Vet". Animals in the control groups were fed $20 \mathrm{ml}$ of saline. The drug was fed in the morning while feeding the animals. Sows were fed twice a day: 9.00-9.30 in the morning and 15.00-15.30 in the evening. The animal is provided with a full-fledged compound feed of its own production according to a special recipe SK-6. Sows in sexual hunting were selected twice a day using a test boar. Selected sows were placed in individual machines and inseminated with artificially pre-diluted semen twice with an interval of 18 hours. Before artificial insemination, sows were kept in group machines for 15 goals. It was found that feeding sows in the physiologically intense period of the sexual cycle of metabolic-neurotropic drugs "Glutam 1M" and "Stimulin Vet" 1-3 days of the sftate cycle had a positive effect on the growth rate of animals, mainly by increasing the number of newborn piglets and contributed increase in the number of business piglets, as well as probably their greater weight, with a class of 1.51 and more $\mathrm{kg}$.

Key words: sexual cycle, piglets, embryonic period, reproductive ability.

Дата надходження до редакції: 18.01.2021 р. 